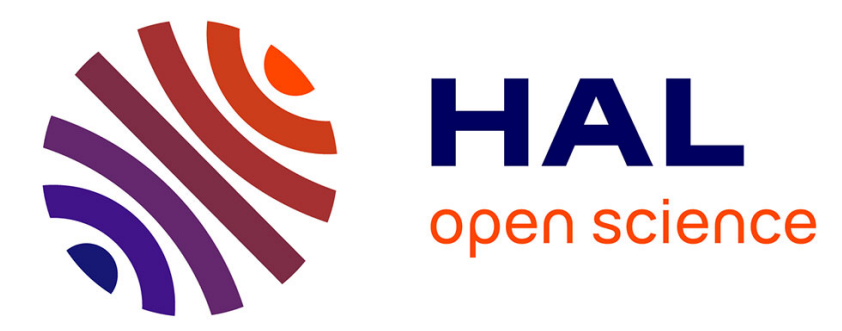

\title{
Preliminary results of a paleoseismological analysis along the Sahel fault (Algeria): New evidence for historical seismic events
}

A. Heddar, Christine Authemayou, H. Djellit, K. Yelles, Jacques Déverchère, S. Gharbi, A. Boudiaf, Brigitte van Vliet-Lanoë

\section{To cite this version:}

A. Heddar, Christine Authemayou, H. Djellit, K. Yelles, Jacques Déverchère, et al.. Preliminary results of a paleoseismological analysis along the Sahel fault (Algeria): New evidence for historical seismic events. Quaternary International, 2013, 302, pp.210-223. 10.1016/j.quaint.2012.09.007 . insu-00841173

\section{HAL Id: insu-00841173 \\ https://hal-insu.archives-ouvertes.fr/insu-00841173}

Submitted on 9 Jul 2013

HAL is a multi-disciplinary open access archive for the deposit and dissemination of scientific research documents, whether they are published or not. The documents may come from teaching and research institutions in France or abroad, or from public or private research centers.
L'archive ouverte pluridisciplinaire HAL, est destinée au dépôt et à la diffusion de documents scientifiques de niveau recherche, publiés ou non, émanant des établissements d'enseignement et de recherche français ou étrangers, des laboratoires publics ou privés. 


\section{Preliminary results of a paleoseismological analysis along the Sahel fault (Algeria):} new evidence for historical seismic events

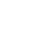

(5)

(1)

6

${ }^{a}$ CRAAG Centre de Recherche en Astronomie Astrophysique et Géophysique, - Route de l'Observatoire Bp 63 Bouzareah - Alger - Algeria

${ }^{\mathrm{b}}$ Université de Brest (UBO), UMR 6538 Domaines Océaniques, 29238 Plouzané, France

${ }^{\mathrm{c}}$ Université de Montpellier, France

\section{Abstract}

The $\sim 60 \mathrm{~km}$-long Sahel ridge west of Algiers (Tell Atlas, north Algeria) is considered as an ENE-WSW fault-propagation fold running along the Mediterranean coast and associated with a north-west dipping thrust. Its proximity with Algiers makes this structure a potential source of destructive earthquakes that could hit the capital city, as occurred in $1365 \mathrm{AD}$ and 1716 $\mathrm{AD}$. The first paleoseismologic investigation on the Sahel ridge was conducted in order to detect paleo-ruptures related to active faulting and to date them. From the first investigations in the area, a first trench was excavated across bending-moment normal faults induced by flexural slip folding in the hanging wall of the Sahel anticline thrust ramp. Paleoseismological analyses recognize eight rupture events affecting colluvial deposits. ${ }^{14} \mathrm{C}$ dating indicates that these events are very young, six of them being younger than 778 AD. The first sedimentary record indicates two ruptures before $1211 \mathrm{AD}$, i.e. older than the first historical earthquake documented in the region. Three events have age ranges compatible with the 1365, 1673 and 1716 Algiers earthquakes, whereas three other ones depict very recent ages, i. e. younger than 1700 AD. Potential of these secondary extrados faults for determining paleoseismic events and thrust behaviour is discussed.

Keywords: Algeria, Sahel, paleoseismology, trench, rupture event, historical earthquake

\section{Introduction}

North Algeria was affected by several large $(M \quad 7)$ earthquakes in recent centuries (Meghraoui et al., 1988; Bezzeghoud et al., 1996). Although strain rates are low compared to those occurring along subduction zones, their impacts on human lives and infrastructures appear to be quite high in the light of this historical knowledge. One of the most seismically 
active areas in Algeria is the part of the Tell Atlas located in Northernmost Algeria (Fig. 1). Many catalogs of seismicity have reported moderate and shallow seismicity punctuated by strong earthquakes (Rothé, 1950; Hée, 1950; Roussel, 1973; Benhallou, 1985; Mokrane et al., 1994; Benouar, 1994; Yelles et al., 2002; Harbi et al., 2004, 2007a). In recent decades, this area has experienced destructive earthquakes, such as Orléansville on 09/09/1954 (M=6.7) (Rothé, 1955), El Asnam on 10/10/1980 (M=7.3) (Ouyed et al., 1980), Tipaza on 29/10/1989 $(M=6.0)$ (Meghraoui, 1991), and Boumerdes-Zemmouri on 21/05/2003 ( $M=6.8$ ) (Ayadi et al., 2003), making this territory one of the most seismic regions in the western Mediterranean. It is a strategic area because of the location of the capital, Algiers, and other major cities, where population and main social and economic activities are concentrated. Geodynamically, the Tell Atlas corresponds to the passive margin of the Algerian back-arc basin, produced by the roll-back of the Tethyan oceanic slab ending with the Miocene collision of the Kabyle blocks with the African plate (Carminati et al. 1998; Gueguen et al., 1998; Vergès and Sabàt, 1999; Frizon de Lamotte, 2000; Jolivet and Faccenna, 2000; Mauffret et al., 2004; Duggen et al., 2004; Schettino and Turco, 2006). Currently, the convergence between Africa and Eurasia reactivates this margin in compression (Thomas, 1976; Domzig, 2006, Domzig et al., 2006, Serpelloni et al., 2007). Analyses of focal mechanisms, GPS, VLBI (Very Long Baseline Interferometry) and SLR (Satellite Laser Ranging) data indicate a NW-SE shortening direction with a convergence rate of about 4-6 mm /y (Anderson and Jackson, 1987; De Mets et al., 1990; Stich et al., 2006; Serpelloni et al., 2007).

This shortening affects faulted and folded structures in the onshore and offshore domains (Thomas, 1976; Philip and Meghraoui, 1983; Domzig, 2006; Domzig et al., 2006; Yelles et al., 2006). Some of these structures are inherited and experienced thrust and/or strike-slip faulting. The most well-known structure in Algeria is the Oued Fodda (El Asnam) NE-SW sinistral reverse fault associated with an anticlinal ramp that generated the strongest earthquake in the western Mediterranean on October 10, 1980 (Ms: 7.3) (Ouyed et al., 1981, 1982; King and Vita-Finzi, 1981; Yielding et al., 1981; Deschamps et al., 1982) (Fig. 1). The first paleoseismological investigation realized in Algeria was made on this fault. It recognized the existence of clusters of large earthquakes alternating with periods of quiescence, and a return period between 300 and 400 years during the active faulting episodes (Meghraoui and al., 1988). Close to Algiers, the Mitidja basin is bounded by several major active structures, which are the sources of potential destructive earthquakes (Meghraoui, 1991; Boudiaf, 1996; Harbi et al., 2004; Guemache et al., 2010; Maouche et al., 2011) (Fig. 1). In the instrumental period, moderate earthquakes $(M<6)$ have been recorded with no surface ruptures (Oued Djer 
event (M 5.5) in 1988; Tipaza event (M 6.0) in 1990; Ain-Benian event (M 5.7) in 1996 (Bezzeghoud et al., 1996; Boudiaf, 1996; Mokrane et al., 1994; Sebaï, 1997). The Mw 6.8 Boumerdes (05/21/2003) earthquake was accompanied by substantial coastal uplift but did not produce observable surface ruptures, probably because it was located offshore (Déverchère et al., 2005, 2010). Nevertheless, the Algiers region has experienced in the historical period damaging earthquakes (e.g., 1365, 1716), (Ambraseys and Vogt, 1988; Harbi and al, 2007a) that have not until now been attributed definitely to a specific structure of the Mitidja basin or surrounding faults.

This paleoseismological study deals with an active structure located north of the Mitidja basin. It focuses on the north-west dipping reverse fault of the Sahel anticline emerging near the Mediterranean shoreline (Figs. 1 and 2). The purpose of this study is to detect surface ruptures that record paleo-earthquakes in an attempt to complement the seismologic catalog of the region and give the first direct evidence of surface ruptures produced by the Sahel structure activity. The investigated site has been selected after analyses of SPOT satellite imagery and field investigations. It is located on the southern flank of the Sahel fault propagation fold, in the region of Kolea city, across extrado-type normal faults affecting recent colluvial deposits (Fig. 2). These flexural faults are associated with the major reverse thrust activity located in the piedmont plain. Until now, no studies have detected the surface breaks of this thrust that appears as a blind structure under the thick Quaternary alluvial deposits of the Mitidja basin. However, paleoseismologic analyses of the secondary normal faults allow reporting for the first time historical seismic ruptures associated with the activity of the Sahel structure. As underlined by McCalpin (2009), the results also show that paleoseismic history derived from secondary faults may be a good proxy for events on the underlying thrust, especially where this latter does not extend to the surface. Secondary faults in the study area form a graben corresponding to a sediment trap with abundant organics for ${ }^{14} \mathrm{C}$ dating.

\section{Seismotectonic framework}

\subsection{Geological setting}

The E-W Mitidja plain is a Middle Miocene to Quaternary intra-continental basin (Figs. 1 and 2) (Glangeaud et al., 1952; Aymé et al., 1954). Its sedimentary filling consists of Miocene to Pliocene marine marls, calcareous and sandstones covered by Quaternary heterogeneous continental deposits that have been subsequently partially eroded (Glangeaud, 1932). The basin was interpreted variously as a graben (De Lamothe, 1911) or a syncline bounded by 
103 compressive structures (Glangeaud, 1932). The lack of seismic profiles and deep wells across

104 the basin prevents knowing its depth, precise timing of development, geometry and dip of the 105 surrounding faults. Only the modeling of recent gravity data has highlighted a deep and steep 106 north-dipping tectonic contact oriented NE-SW at the northern basin boundary (Hamaï, 107 2011).

108 The Mitidja basin is surrounded by relief belonging to different structural domains, namely 109 the Atlas of Blida Mountains to the south and the Chenoua-Sahel-Bouzareah relief to the 110 north (Fig. 1). To the south, the Atlas of Blida Mountains reaches $1500 \mathrm{~m}$ height. This relief 111 consists mainly of Tellian units composed of flysch and Cretaceous deposits (Blès, 1971). 112 The northern boundary of the Blida Atlas Mountains shows Pliocene deposits dipping to the 113 north affected by a reverse fault (Glangeaud et al., 1952; Bonneton, 1977; Boudiaf, 1996; 114 Guemache, 2010; Guemache et al., 2010). This reverse fault extends to the east, close to the 115 coastline (Meghraoui et al., 2004; Ayadi et al., 2008). Boudiaf (1996) has recognized 116 Quaternary activity on this structure.

117 To the north, the Mitidja basin is separated from the Mediterranean Sea by the Chenoua and 118 Algiers-Bouzareah massifs which are relics belonging to the Internal Zones (Durant-Delga, 119 1969) formed by discontinuous massifs spread along the coast. The Bouzareah massif is made 120 of a metamorphic block (Saadallah, 1981), whereas the Chenoua massif comprises a 121 sedimentary sequence from the Devonian to the Oligocene (Belhai, 1987, Belhai et al., 1990) 122 (Fig. 2). The latter massif is bounded to the south by a $10 \mathrm{~km}$-long EW-trending reverse fault 123 bent northeastward in the offshore domain (Meghraoui, 1991).

124 Between the two massifs, the $60 \mathrm{~km}$-long WSW-ENE Sahel ridge runs along the coast. It is 125 formed by hills of moderate altitude $(\sim 200 \mathrm{~m})$ and tablelands, and shows a morphological 126 discontinuity formed by the across-strike valley of the Mazafran River (Fig. 2). The Sahel 127 structure is generally interpreted in two ways. Aymé et al. (1954) proposed that the ridge 128 corresponds to a monoclinal series of Neogene deposits formed of Miocene and Pliocene 129 marls and sandstones (Fig. 2, cross-section B). More recently, several authors (Meghraoui, 130 1988, 1991; Maouche et al., 2011) interpreted this structure as a south-verging asymmetric 131 fault-propagation fold formed by Pliocene units overlapped by marine terrace deposits 132 (Aymé, 1952; Saoudi, 1989) that was developed in response to the motion on a $60 \mathrm{~km}-\mathrm{long}$ 133 north-west dipping blind thrust fault, south of the ridge, which they refer to as the Sahel fault 134 (Fig. 2, cross-section A). Offshore, two other $20 \mathrm{~km}$-long NE-trending reverse faults have 135 been detected affecting the upper Khayr-al-Din bank (Yelles et al., 2009; Fig. 2). 
136 This study focuses on the largest structure of the northern boundary of the Mitidja basin, the

137 Sahel ridge, which represents a young tectonic feature formed after the Pliocene. To compare 138 the two interpretations of an onshore anticline (Megrahoui, 1991) or onshore monocline 139 (Aymé, 1954), it is proposed that the Sahel ridge is an anticline potentially extending 140 offshore. This discrepancy is secondary for the purpose of this study, as the aim is to establish 141 paleoseismological analyses across secondary faults associated with the blind thrust on the 142 southern Sahel flank.

143

\subsection{Historical and instrumental seismicity}

145 Many studies producing catalogs on historical seismicity report several earthquakes that have 146 struck Algiers and its surroundings, but their locations remain uncertain or controversial 147 (Rothé, 1950; Benhallou et al., 1971; Roussel, 1973; Ambraseys and Vogt, 1988; Mokrane et 148 al., 1994; Benouar, 1994; Harbi, 2006; Harbi et al., 2004, 2007a; Sebaï and Bernard 2008;

149 Fig. 1). Among the most cited events, a major earthquake occurred on January 3, 1365, 150 striking Algiers, inducing a tsunami, followed by about 500 aftershocks (Harbi et al., 2007a). 151 This damaging earthquake was located either offshore or near the coast, with an intensity $(I)$ 152 of $\mathrm{X}$ on the EMS scale. Another event on February 3, 1716, much more documented (Perrey, 153 1847; Mokrane et al., 1994; Rothé, 1950; Benhallou et al., 1971; Roussel, 1973; Ambraseys 154 and Vogt, 1988; Harbi et al., 2004; 2006; 2007a), destroyed a large part of Algiers and Blida 155 (a city located $30 \mathrm{~km}$ to the south of Algiers). It caused the loss of 20,000 lives. Harbi et al. 156 (2007a) located its epicenter close to Douera in the Algiers Sahel, and Sebaï and Bernard 157 (2008) located it close to Algiers. Other historical earthquakes of intensity VIII have affected 158 the region near Algiers in 1673 and 1842 (Harbi et al., 2007a). Some other larger historical 159 earthquakes are documented, but their location or intensity are doubtful (in 1522 north of 160 Tipaza, located at the western part of the Sahel structure (I: IX); in 1658 around the Chenoua 161 Massif, in 1804 around Sidi Fredj, located at the coastline of the Algiers massif (I: IX) and in 1621860 north of Tipaza (I: VIII).

163 Seismic monitoring began in Algeria after the 1980 El-Asnam earthquake (M 7.3). However, 164 the record has been continuous only since the establishment of the digital network in 2005. 165 This explains the lack of microseismicity recording necessary in order to identify and monitor 166 active structures. A moderate to low seismicity seems to be clustered near Algiers. Some 167 small events are located westward of the valley of Mazafran River (Fig.1 and 2). Recently, 168 two events occurred on 20-05-2010 (M 4.2) and on 23-11-2011 (M 3.4) that have been felt by 169 the population in the region of Algiers. They were located $4 \mathrm{~km} \mathrm{SW}$ of Douera for the first 
170 one and $4 \mathrm{~km} \mathrm{SE}$ of Douera for the second (Centre de Recherche en Astronomie, 171 Astrophysique et Géophysique (CRAAG), 2010; 2011) (Fig. 1). Instrumental seismicity has 172 allowed identification of some active zones and focal mechanisms (Fig. 1). The most 173 important events are: Chenoua (M: 6.0) on 29/10/1989; Ain El Benian (M: 5.7), on 174 04/09/1996; and Boumerdes (Mw:6.8), on 21/05/2003 (Meghraoui, 1991; Maouche et al., 175 1998; Bounif et al., 2003; Harbi et al., 2004, 2007b; Déverchère et al., 2005; Yelles et al., 176 2004, 2006). These events are related to offshore faults close to the coast and are 177 characterized by reverse focal mechanisms (Fig. 1). Despite the substantial seismicity in the 178 Sahel region, no clear evidence of surface break after an earthquake was found.

\section{Paleoseismicity study}

\section{3.1. Trench location}

182 Satellite images analyses, gravimetry data (Hamaï, 2011) and field investigations were used to select a site in the south area of Kolea city, located $40 \mathrm{~km} \mathrm{SW}$ of Algiers, on the southern flank of the Sahel fold (Fig. 2). The first witnesses of active faulting near the surface were highlighted by an abrupt change of the dip of the Astian upper layers from $31^{\circ}$ to $84^{\circ}$ toward the SSE (sites 1 and 2, Figs. 2 and 3). This sharp flexure could have been produced by short wave-length folding associated with motion along the major thrust.

188 Near these sites, visible on a SPOT 5 satellite image, is a morphological scarp $5 \mathrm{~m}$ high, 189 suspected as the fault trace of the major Sahel thrust (Fig. 4a). A paleoseismological analysis of this scarp did not reveal fault ruptures but only gentle horizontal alluvial sediments and marls above them (see Appendix). The scarp was formed by differential erosion of the upper marl with respect to the conglomerates induced by incision of the surrounding Mazafran

193 River. Thus, it is suspected that the Sahel thrust would be masked by thick alluvial deposits.

194 However, 200-m upward from the scarp (Fig. 4b), in the slope of the southern flank of the

195 Sahel ridge, trench metric-scale normal faults affecting partially masked surface deposits are 196 exposed in earthworks. Farm activity has removed their geomorphologic expression at the 197 surface: however, cleaning revealed a local graben structure $5 \mathrm{~m}$-long and $1.5 \mathrm{~m}$-deep 198 affecting pedogenic marls filled by various ruptured colluvial deposits rich in charcoal (Fig. 5). After the enlargement of the earthwork trench in May 2012, a major 20-m high normal fault dipping to the north was observed $8 \mathrm{~m}$ southward, affecting Pliocene sandstones and forming a half-graben filled by Quaternary conglomerate deposits. This Quaternary infilling extended deeper into the fault plane, forming a fissure fill facies suggesting piping process or 
204

205

206

207

208

209

210

211

212

213

214

215

216

217

218

219

220

221

222

223

224

225

226

227

228

229

230

231

232

233

234

235

236

237

and Coates, 1990; McCalpin, 2009). These extensional structures are commonly observed in anticlinal ramp systems, named extrados faults or moment-bending faults: they are produced by flexural slip folding during motion along the anticlinal ramp (Fig. 4b). These kinds of structures have been observed and described in Iran on the hanging wall of the Tabas thrust during the 1978 Tabas-e-Goldshan earthquake (Berberian, 1979), in Algeria on the Oued Fodda fault-propagation fold during the 1980 El-Asnam damaging earthquake (Philip and Meghraoui, 1983), south of the Chenoua Massif during the 1989 Mont Chenoua-Tipaza earthquake (Meghraoui, 1991), and on the Sahel structure (Maouche et al., 2011). Faults encountered on this latter site must have the same tectonic origin, especially as the gentle dip of the slope of $6-7^{\circ}$ to the south and the dip of the normal faults opposite to this slope prevent interpreting them as effects of gravity motion.

During spring 2011, a paleoseismological study focused on the normal faults of the graben, because even if these secondary faults are not large enough to be seismogenic, paleoseismic histories derived from them may be good proxies for events on the underlying seismogenic thrust, especially where this one does not extend to the surface (McCalpin, 2009). The interest in this structure relies is that the graben is a sediment trap with an important number of units rich in organics for ${ }^{14} \mathrm{C}$ dating, affected by several normal faults that allow recording a nonnegligible number of paleo-events. After having established an arbitrary system grid, the trench was logged in detail, allowing a precise description of the deposits and paleosurface ruptures.

\subsection{Stratigraphic Sequences}

The wall of the trench exhibits an elongated depression controlled by faulting as a graben structure and filled by a well-defined sequence of tens of sub-horizontal colluvial deposits (Fig. 5). The faults affect thick units of ochre white-spotted pedogenic marls corresponding to alteration clay (unit 2) in contact to the south with tilted alluvial deposits (Unit 1). The younger colluvial deposits (U3 to U12) were trapped in the graben, interpreted to be produced by flexure in the hanging-wall of the anticlinal ramp thrust during successive seismic events.

The non-erosive flat boundaries between Units 3 to 10 indicate that most of the layers were deposited without significant erosion of the underlying unit before deposition on a gentle dipping slope. However, fragments of marls, more or less numerous from unit to unit, indicate that the substratum of marls was eroded to feed in part the colluvial deposits as a scarpderived colluvium (McCalpin, 2009). These deposits have various colors, thicknesses and extents and contain charcoal and shells (Fig. 5). Two different groups of units were 
distinguished according to their lithologic contents. The limit between them is located at 1.10 $\mathrm{m}$ below the surface. The lower group is made of ochre detrital units (U3 to U5) with a maximum total thickness of $22 \mathrm{~cm}$. These colluvial deposits are mainly composed of millimetre to centimetre gravels in a silty clay matrix.

242 The upper group (U6 to U12) includes units of brown to light clay, including a peat horizon.

243 These layers are essentially composed of silty clay containing shells and detrital charcoal.

244 Their colors vary from dark brown to yellow according to their abundance of organic matter.

245 A dark and thin peat horizon $\sim 5 \mathrm{~cm}$-thick (U8) is interstratified in the middle of the sequence

246 (Fig. 5). Unit 12 is unconformable above the older units, indicating a dominant erosional

247 control on its deposition. Unit 12 is rich in pedogenic marls provided by the denudation of the

248 marl substratum (U2). Finally, a brown surface layer of $\sim 40 \mathrm{~cm}$ thick containing some detrital

249 charcoal seals the graben (U13) (Fig. 5).

250 According to the unit characteristics, the infill of the depression is related to sheet wash erosion by local heavy precipitation as also shown laterally by piping at the level of the fault (Fig. 6) (Higgins and Coates, 1990). Because of the location and orientation of the graben in

253 the general slope of the southern limb of the Sahel ridge and normal to the slope dip, sedimentation is more related to colluvial activity than to fluvial influx, as indicated by the shortage of gravels and lack of erosive discontinuities. The sequence corresponds to a step by step infill of a depression with temporary stabilization allowing organic matter accumulation

\section{7 (Unit 8).}

\subsection{Age control}

260 In order to date the ruptures observed in the trench, we have sampled eleven detrital wood 261 fragments and gastropod shells in all units, except U3 and U5 which do not contain any 262 organic matter for ${ }^{14} \mathrm{C}$ dating (Fig. 5, Table 1). Gastropod shells correspond to Helix aspera in 263 Unit 4 (e1) and Unit 7 (e3). Caution in extracting samples has been taken to avoid 264 contamination. Samples were prepared for ${ }^{14} \mathrm{C}$ accelerated mass spectrometry (AMS) and 265 dated at the Poznan radiocarbon laboratory in Poland and at the Center for Applied Isotope 266 Studies University of Georgia (CAIS) in USA (Table 1). The ${ }^{14} \mathrm{C}$ ages were corrected for 267 changes in the atmospheric ${ }^{14} \mathrm{C} /{ }^{13} \mathrm{C}$ ratio over the last few millennia using IntCal, an on-line 268 CALIB Manual 6.0 radiocarbon calibration tool hosted by the Quaternary Isotope Laboratory 269 at the University of Washington, UK (http://calib.qub.ac.uk). For more accuracy, dates of 270 samples with a weight inferior to $0.2 \mathrm{mgC}$ were not considered, because they were indicated 271 as unreliable by the Poznan radiocarbon laboratory (e2, e4, e9, Table 1). Furthermore, 
272 samples with calibrated ages younger than 1750-1800 A.D. were described as "modern"

273 because they are located on the "plateau" of calibration and cannot be easily calibrated (e7, 274 e8, e9, e11, Table 1).

275 Samples of Units 4, 7, 8 have radiocarbon calibrated age ranges of 778-897 A.D., 1171-1211 276 A.D. and 1727-1779 A.D., respectively (Table 1, Fig. 5). The samples extracted in the middle 277 of Unit 9 and in the boundary of Units 9 and 10 are dated at 1304-1365 A.D. and as 278 "modern", respectively. The sample of the base of U12 provides a calibrated radiocarbon age 279 of 1455-1654 A.D. Samples of Units 10 and 13 are "modern".

280 Six of the eight ages are in stratigraphic order (Fig. 5). They correspond to samples collected 281 in Units 4, 7, 8; at the boundary between Units 9 and 10; in Unit 10; and Unit 13. The samples 282 of Units 9 and 12 give ages older than the age of the underlying unit. These anomalies suggest 283 that the samples have been reworked and redeposited several times. Sample dates in 284 stratigraphic order suggest rapid colluvial reworking and sedimentation, whereas the other 285 ones suggest multiphase reworking before sedimentation, which explains why younger dates 286 are below the dated unit. Furthermore, reworking is also suggested by weathered sampled 287 gastropods not observed in life position. With the process of reworking, all samples are older 288 than colluvial deposits, and thus give only a maximum age for each unit. Samples with older 289 dates than underlying samples (e6, e10) are useless because a better maximum age is given by 290 the dated underlying unit. Therefore, they will not be taken into account for the 291 paleoseismological interpretations.

292 Consequently, as Unit 4 has a sample date of 778-897 A.D. and is younger than Unit 7 293 associated with a sample dated at 1171-1211 A.D., Unit 4 is younger than 778 A.D. and older 294 than 1211 A.D. Concerning Unit 7, it contains a sample dated at 1171-1211 A.D., and the unit 295 is older than Unit 8, including a sample dated at 1727-1779 A.D. Thus, Unit 7 is younger than 2961171 A.D. and older than 1779 A.D. Unit 8 has a sample age of 1727-1779 A.D.: 297 consequently, this unit is younger than 1727 A.D.

298 A minimum age could be attributed to Unit 8 and the above units containing "modern" 299 samples because the presence of a thick surface brown unit (U13) on top of these units 300 strongly suggests that it was formed after the agricultural reform in 1963 A.D. (Bessaoud, 301 1980). Thus, units designated "modern" have a range of ages between 1750 and 1963 AD 302 (Reimer et al., 2009).

303 
305 Considering the position of the outcrops relative to the blind, active thrust of the Sahel 306 anticline (Fig. 4b), offsets along normal faults observed in the trench are interpreted as effects

307 of flexure with extrados deformation related to the incremental growth of an anticline ramp in 308 the hanging wall of the blind thrust, produced during earthquakes in a way similar to what has 309 been reported in El Asnam site (Philip and Meghraoui, 1983; Meghraoui et al., 1988). 310 Analyzes of these extensional structures are critical to distinguish surface ruptures during 311 major paleo-earthquakes when the major thrust is blind (McCalpin, 2009).

312 A piece of evidence that the sediment trap in pedogenic marls corresponds to a graben is the 313 staircase geometry of its boundaries. Steep walls cannot be formed by erosion of marls; 314 because they would be smoother with gentle slopes. Each step must be bounded by a normal

315 fault, such as the surrounding normal fault located 8-m southward (Fig. 6). Furthermore, the 316 location of the sediment trap in the general slope of the southern limb of the Sahel anticline 317 and normal to the slope dip preclude characterizing it as a small erosional valley (Fig. 4b).

318 Different structural and sedimentological markers in the trench allow recognition of eight 319 rupture events associated with normal faulting. These markers correspond to sub-vertical 320 offsets of units along faults, and commonly folding of units on top of a fault termination, 321 because the clay-rich sediments result in plastic accommodation of the deformation. Drag 322 folds were observed close to the fault; shear zone or steep fault scarps bounded by units 323 representing colluvial wedges (Figs. 5a, b). Generally for the latter case, immediately after 324 faulting, the space produced by motion along a normal fault affecting a sloping surface is 325 filled by colluvial deposits mainly near the free face due to the continuous slope erosion by 326 streaming (McCalpin, 2009). The final geometry of the colluvial unit is generally asymmetric with a maximum thickness at the fault plane. If two antithetic normal faults have the same amount of motion during one event, the colluvial deposit shape is roughly symmetric. The thickness of the colluvial unit corresponds to the minimum offset along the fault for one event because the deposit and the fault scarp can be partially eroded.

331 In the trench, the 5m-long depression striking NW-SE exhibits five normal steep antithetic 332 metric-scale faults labeled A, B, C, D, and E (Fig. 5). Two (A and B), situated downward, dip 333 to the north, and the three others (C, D and E) dip to the south. They affect Units 3 to 12 334 differently.

335 Fault A constitutes the edge of Units 4, 5, 6, 8, 9, 10 and 12, with a thickening of Units 4, 5 336 and 6 near the fault (Fig. 5). The fault plane corresponds to a steep wall of marls and a shear 337 zone downward in the marls (Fig. 5a). Units 4, 5, 8 and 10 exhibit drag folds, indicating that 338 motion along the fault has affected these units. Fault B forms a fault plane that becomes 
divided into two branches from Unit 6 . It bounds Units 3 and 7, indicating that its motion has controlled their deposition during two successive events. This motion has also shifted the base of Units 5,6 and 8 with a cumulative offset of $30 \mathrm{~cm}$ for Unit 5 and 6 and $17 \mathrm{~cm}$ for Unit 8 (Fig. 5). Finally, the northern branch of the fault activity has flexured Units 9 and 10 of $11 \mathrm{~cm}$ and $8 \mathrm{~cm}$, respectively. Fault $\mathrm{C}$ forms the northern edge of Units 3, 4, 5. Fault D bounds Unit

3447 and seems to be associated with an offset of Unit 8 of $8 \mathrm{~cm}$ of amplitude (Fig. 5b). Fault E 345 bounds Unit 9.

\subsection{Sequence of events}

348 Retrodeformation analysis involves restoring stratigraphic units to their (inferred) original geometries by graphically reversing the sense of displacement on faults. Eight rupture events were recognized in the trench according to the markers of fault motions associated with the deposition of units and their respective deformations (Fig. 7). Rupture events have contributed to the incremental widening of the graben. According to the paleoseismological analysis, each event is characterized by (potentially coseismic) displacements along one to four secondary, normal faults (Fig. 7). Potential co-seismic displacements are generally in the range of 3 to 25 $\mathrm{cm}$ along the faults.

356 A first surface rupture (E1) created two antithetic normal faults B and C located currently in 357 the middle of the graben (Figs. 5 and 7). The faults were initiated into the pedogenic marl 358 (U2) and produced a graben $50 \mathrm{~cm}$ wide, filled by Unit 3. The constant thickness of Unit 3 (3 $\mathrm{cm}$ ) provides a minimum of motion during E1 along the faults B and C. This rupture event occurred before Unit 3 deposition (Fig. 7).

361 The presence of Unit 4 bounded by Fault A, in contrast to Unit 3 limited by Fault B to the

362 south, implies a new rupture event. Event 2 (E2) reactivated faults B and C, and produced a 363 new north-dipping fault (fault A) enlargening the graben on the southern side. The graben was 364 filled with Unit 4 deposit in two depocenters: (1) The southern one corresponds to a half fan365 shaped graben with $8 \mathrm{~cm}$ maximum depth and bounded by fault $\mathrm{A}$ : this depth corresponds to 366 the minimum offset produced along fault A during Event E2; (2) The northern depocenter is 367 filled with $7 \mathrm{~cm}$-thick Unit 4 implying a minimum offset of $7 \mathrm{~cm}$ along faults $\mathrm{B}$ and C. Event 368 E2 occurred before deposition of Unit 4 dated between 778-1211 A.D., and after deposition of 369 Unit 3.

370 The third recorded event (E3) allowed the sedimentation of the $9 \mathrm{~cm}$-thick Unit 5 between 371 faults $\mathrm{A}$ and $\mathrm{C}$, sealing Fault B. Event E3 thus reactivated faults $\mathrm{A}$ and $\mathrm{C}$ with a minimum 
372 displacement of $9 \mathrm{~cm}$ (Fig. 7). Event E3 occurred after the deposition of Unit 4, dated 373 between 778-1211 A.D. and prior to the sedimentation of Unit 5.

374 Because Unit 6, in contrast to to Unit 5, has a colluvial wedge geometry another rupture event 375 after Unit 5 deposition was needed to create a new fault scarp. This Event 4 (E4) occurred 376 prior to the asymmetric deposition of Unit 6 north of Fault A. The southward thickening of 377 Unit 6 to $21 \mathrm{~cm}$ toward fault A suggests a tilting of Unit 5 produced by a minimum offset of $37821 \mathrm{~cm}$ along Fault A during E4. Northward, Fault C could have been also reactivated as it 379 bounds a $4 \mathrm{~cm}$-thick lower part of Unit 6 . This measure could correspond to the minimum 380 offset on Fault $\mathrm{C}$ during this event.

381 A new event rupture must be inferred after Unit 6 deposition because a new unit (Unit 7) 382 appears only to the north of Fault B. To allow this sedimentation, Event 5 (E5) must have 383 produced new displacements along Fault B that offsets Units 6 and 5, creating Fault D that 384 enlargened the graben towards the north. Motion along these faults (B and D) allowed the 385 deposition of Unit 7 sealed by Unit 8. Consequently, E5 occurred between the deposition of Units 6 and 8 and is therefore older than 1779 A.D. (maximum age of U8). The thickness of this unit gives a minimum offset during Event 5 (E5) of $12 \mathrm{~cm}$ and $7 \mathrm{~cm}$ along faults B and D, respectively. This is in agreement with the difference of offsets of Units 8 and $6(30-17 \mathrm{~cm})$ along fault B.

390 Several offsets of Unit 8, and the colluvial wedge geometry of Unit 9 near Fault E, indicate a 391 new rupture event. Event 6 (E6) affected Unit 8, reactivating faults A, B and D, and initiating 392 Fault E. It produced drag-folds of Unit 8 along faults $A$ and E. The induced depression 393 between them was filled with Unit 9. Thus, this event occurred between the deposition of Unit 3948 after $1727 \mathrm{AD}$ and the deposition of Unit 9. The thickness of Unit 9 near Fault E gives a 395 minimum offset on fault E of $25 \mathrm{~cm}$ during Event 6 (E6) or (E5). Unit 9 near Fault A and the 396 drag-fold of Unit 8 has a thickness of $3 \mathrm{~cm}$. This value is the minimum offset on Fault A 397 during Event E6 or E5 (Fig. 7). Event E6 or E4 also produced a vertical offset of $6 \mathrm{~cm}(17 \mathrm{~cm}$ $398-11 \mathrm{~cm}$ of U8 and U9 total offset, respectively) along Fault B and the folding of $8 \mathrm{~cm}$ of 399 amplitude of Unit 8 by motion along Fault D. These offsets are sealed by Unit 9.

400 According to the location of Unit 10 near the free surface of the steep scarp of Fault A with a 401 thickness decreasing moving away from the fault, a new rupture event is suggested. Event 7 402 (E7) reactivated Fault A, allowing Unit 10 deposition associated with a "Modern" sample age. 403 It is thus younger than 1750 A.D. (maximum age of unit 10, as this age is the lower boundary 404 of "plateau" process during age calibration). The thickness of Unit 10 near Fault A provides a 405 minimum offset of $15 \mathrm{~cm}$ on the fault during this event. 
406 Because Unit 10 is slightly warped above Fault B and Unit 11 is bounded between Fault A 407 and Fault E (Fig. 4), Event 8 (E8) seems to have reactivated faults A, B and E after the 408 deposition of Unit 10 dated at a minimum of 1750 A.D. After this event, two episodes of sedimentation (U11 and U12) followed. The discordance of Unit 12 on Units 10 and 11 (Fig.

410 5) and the amount of pedogenic marls coming from the surrounding Unit 2 suggest that its 411 deposition was favored by erosion. Finally a surface layer of $40 \mathrm{~cm}$-thick seals all the layers 412 of the graben. It formed after the agricultural reform in 1963 A.D. Consequently, this date 413 would be the maximum age of events 6,7 and 8 .

414

\section{4. Discussion}

\section{4.1. Correlations between rupture events and historical events}

417 The young ages of the determined rupture events allow comparison between them and the 418 record of historical earthquakes near Algiers (Fig. 8). The historical record of felt earthquakes 419 in the Algiers region extends discontinuously back over 700 y (Rothé, 1950; Roussel, 1973; 420 Benhallou, 1985; Ambraseys and Vogt, 1988; Mokrane al., 1994, Yelles et al., 2002; 421 Benouar, 2004; Harbi et al., 2007a; Sebaï and Bernard, 2008; Hamdache et al., 2010). Only 422 historical events in the region associated with intensity greater than VIII and historical 423 earthquakes of intensity equal to IX or X were considered (Fig. 8). This selection was made to 424 consider only potential historical earthquakes associated with fault rupture with a magnitude 425 larger than 5.5 (McCalpin, 2009). Even if the relation between intensity and magnitude is very difficult to assess, depending on several parameters, historical earthquakes with intensity of VIII could potentially mean a magnitude larger than 5.5 (Gere and Shah, 1984). However, a distinction was made between large historical earthquakes (I: IX-X) and moderate historical earthquakes (I: VIII), the first being more favorable to generate surface ruptures and thus to be recorded in the paleoseismologic trench. Unambiguous historical earthquakes are also distinguished from earthquakes associated with a doubtful location (Fig. 8).

432 Events 1 and 2 predate U4 deposition. Since U4 predates U7, younger than 1171-1211 AD, 433 these two events must have occurred before 1211 AD. If U4 deposition occurred 434 consecutively and shortly after Event 2 in order to fill the graben produced by fault motion by 435 slope leaching, Event 2 must have occurred between 778 and 1211 AD, the range age of Unit

436 4. However, reliable historical accounts of earthquake activity in Algiers region prior to this 437 period are unavailable. This lack of historical data is due to the disrupted history of Algeria 438 between the 8th and 15th centuries. Before $1453 \mathrm{AD}$ and the Ottoman Empire colonisation, 439 several Muslim dynasties followed one another in the region after $776 \mathrm{AD}$. This permanent 
440 instability of authority prevented the conservation of ancient archives of the region (Harbi et 441 al., 2007a).

442 The following events (E3, E4 and E5) occurred between the deposition of U4 and U7. 443 Because the maximum age of $\mathrm{U} 4$ is $778 \mathrm{AD}$ and the minimum age of $\mathrm{U} 7$ is $1727 \mathrm{AD}$, the 444 three events occurred between 1211 AD and 1727 AD. During this period, three significant 445 historical earthquakes and two doubtful events with intensity over VIII could have produced 446 surface ruptures (Fig 8). They occurred on January 3, 1365 (I: X), September 22, 1522 (I: IX), 447 December 31, 1658 (I: VIII), May 10, 1673 (I: VIII) and February 3, 1716 (I: IX-X) (Event A 448 to E, Fig. 8) (Harbi et al., 2007a). The 1522 Tipaza earthquake, which magnitude is estimated 449 at 6.5 (Hamdache et al., 2010), is considered as doubtful because it occurred the same day as 450 the Almeria earthquake, off Spain, with a magnitude of more than 6.5 (Reicherter and Becker451 Heidmann, 2009). The first large historical earthquake in 1365 is often listed in historical 452 earthquake catalogs and is well-documented. It caused great damage and produced a tsunami 453 and flooding in Algiers. The 1716 earthquake is known as the strongest event that occurred in 454 Algiers during historical times. This earthquake destroyed the city of Algiers, overturning 2/3 455 of houses and damaging the remaining ones (Ambraseys and Vogt, 1988; Harbi et al., 2007a). 456 Due to their location (Fig. 1) and their intensity, these two earthquakes are good candidates to 457 correspond to one of the rupture events E3, E4 and E5. However, without more precise unit 458 dating, unambiguous correlation of one rupture event with one known historical earthquake is 459 not possible. Event 5 could have occurred just before Unit 7 deposition, as the deep fault 460 scarp B bounding the unit seems protected against erosion. As U7 range age is between 1171 461 and 1779 A.D., the same range age is suggested for Event 5, with a potential link of both 462 events with the reported historical earthquakes.

463 Events 6, 7 and 8 postdate Unit 8 deposition, younger than 1727-1779 AD and before the 464 agricultural reform in 1963 AD. During this period (1727-1963), only one certain historical 465 earthquake happened, on December 4, 1842 (I: VIII) (Event G, Fig. 8), and two doubtful 466 events are presumed to have occurred in 1804 (I: IX) (Event F, Fig. 8) and 1860 (I: VIII) 467 (Event H, Fig. 8). Additionally, catalogs report another earthquake that destroyed Kolea on 468 November 7, 1802 (Sebaï, 1997). Consequently, it is difficult to attempt a correlation. 469 However, as only the 1842 event is certain, it could correspond to one of the three recent 470 surface rupture events.

471

472 4.2. Record of rupture events associated with the Sahel fault motion and interval recurrence 
473 There is evidence for eight surface-rupturing events in the analysis of the stratigraphic 474 exposure of the Kolea trench, with six ruptures produced after 778 AD. The close interaction 475 between sedimentation, erosion, and tectonic processes requires caution in paleoseismological

476

477

478

479

480

481

482

483

484

485

486

487

488

489

490

491

492

493

494

495

496

497

498

499

500

501

502

503

504

505 analysis. The erosion does not discount the possibility that some paleo-events were not recorded in this trench, as slip may significantly change from one place to another, and because ruptures during moderate- or even large-size events on this fault did not necessarily reach the surface at this place. It is therefore likely that this paleoearthquake record of the Sahel structure is partial. Furthermore, McCalpin et al. (2011) have shown that not every thrusting event is unambiguously expressed as bending-moment displacement in the break zone. This potential gap of data increases with the fact that the trench does not span the entire width of the deformation zone.

Consequently, the incomplete paleoseismicity record of the Sahel fault activity and the youth of events prevent determination of a well-constrained recurrence interval of major earthquakes associated with the Sahel structure. However, three unambiguous rupture events occurred between 778 A.D. and 1727 A.D. (E3 or E3' and E5 or E4'), implying a theoretical recurrence interval of around $300 \mathrm{y}$. The three younger rupture episodes between $1727 \mathrm{AD}$ and 1963 AD indicate an interval three to four times shorter. This discrepancy could be explained in different ways: (1) the lack of dating for some units may mean that the lower age boundary of Event 3 is more recent than $778 \mathrm{AD}$; (2) some clustering events are major paleoearthquakes followed by aftershocks and relaxation of the structure; or (3) the Sahel structure has undergone a recent pulse of activity. This latter hypothesis agrees with the conclusion made according to the paleoseismological analysis of the El Asnam thrust fault reactivated during the October 10, 1980 event (Philip and Meghraoui, 1983; Meghraoui and al., 1988), where clusters of large seismic events appear around $4000 \mathrm{BP}$ and during the last $1000 \mathrm{y}$, separated by a quiescent period of ca. $1800 \mathrm{y}$. This particular seismogenic fault behavior could also apply to the Sahel structure. However, as the trench does not span the major thrust, co-seismic displacements along this fault during detected rupture events are unknown and prevent estimation of the magnitude associated with these paleo-earthquakes.

\section{Conclusion}

This paper has presented the first paleoseismological study along the Sahel structure, and the second in Algeria since the 10 October 1980 El Asnam earthquake (Ms: 7.3), which was associated with the best-documented example of seismic compressive structure in North 
506 Africa, combining coseismic folding, thrust faulting and secondary extrados normal faulting

507 (King and Vita-Finzi, 1981; Philip and Megharoui 1983; Meghraoui, 1988).

508 The purpose of the study was to establish the first record of paleoseismic events associated

509 with the Sahel compressive structure. The trench was dug in the hanging wall of the Sahel

510 blind thrust, where bending-moment normal faults produced by flexural slip folding were

511 encountered. The logging of the trench (Fig. 5) was made manually and the retro-deformation

512 analysis (Fig. 7) provides evidence for eight surface ruptures. Two events are older than 1211

$513 \mathrm{AD}$, three events occurred between $778 \mathrm{AD}$ and $1779 \mathrm{AD}$, and three are younger than 1727

514 A.D. Thus, two events are older than the older known historical earthquake (the 1365 Algiers

515 event of $\mathrm{X}$ intensity) and three rupture events have range ages compatible with the famous

5161365 and 1716 Algiers historical events. The younger ruptures events forms a pulse that could

517 be interpreted as effect of one major earthquake followed by aftershocks or relaxation of the

518 structure, or a recent increase of the Sahel structure activity that favors the concept of a 519 periodicity of ruptures, a behavior already suggested in the case of the El Asnam fault

520 (Meghraoui et al., 1988). Although no accurate return periods can be inferred from the

521 observations on the secondary fault system, the results suggest that mean recurrence interval

522 is of the order of 200-250 years over recent times (i.e., since $1 \mathrm{ka}$ ).

523 Although this study provides preliminary paleoseismological data of the Sahel structure,

524 important issues remain open, such as estimates of the recurrence intervals of major events

525 over a longer time span, and magnitude or coseismic slip variability. Direct trenching of the

526 main Sahel thrust fault would be a critical issue in the future in order to determine the

527 magnitude of paleoearthquakes, provided the rupture zone is not too deep. Future trenches

528 and more measurements across the entire zone of surface deformation may provide answers to

529 these issues, and appear thus to have the potential to significantly improve knowledge of the

530 seismic hazards in the area of Algiers.

531

\section{Acknowledgements}

533 This work was supported by the Algerian Research Center in Astrophysics, Astronomy and

534 Geophysics (CRAAG), and was partially funded by the French CNES-TOSCA project. The

535 authors would like to thank Prof. dr hab. Tomasz Goslar from Poznań Radiocarbon

536 Laboratory in Poland for his help in the dating, as well as the inhabitants and the local

537 authorities of Kolea city (Algeria) for their help. We thank the anonymous reviewer for

538 comments which improved the manuscript. 


\section{References}

Ambraseys, N., Vogt, J., 1988. Material for the investigation of the seismicity of the region of Algiers. European Earthquake Engineering 3, 16-29.

Anderson, H., Jackson, J., 1987. Active tectonics of the Adriatic Region. Geophysical Journal of the Royal Astronomical Society 91: 937-983. doi: 10.1111/j.1365246X. 1987. Tb 01675. x.

Ayadi, A., and 27 authors, 2003. Strong Algerian earthquake strikes near capital city. Eos, Transactions, AGU 84, 50, 561- 568.

Ayadi, A., Dorbath, C., Ousadou, F., Maouche, S., Chikh, M., Bounif, M.A., Meghraoui, M., 2008. Zemmouri earthquake rupture zone (Mw 6.8, Algeria): Aftershocks sequence relocation and 3D velocity model. Journal of Geophysical Research 113, B09301, doi:10.1029/2007JB005257.

Aymé, A., 1952. Le quaternaire littoral des environs d'Alger. Proceeding of the Pan-African Congress of Prehistory, Session II. Algiers, Algeria, pp. 243-245.

Aymé, A., Aymé, J. M., Magné, J., 1954. Etude des terrains néogènes de la cluse de Mazafran (Sahel d'Alger). Travaux des collaborateurs. Bulletin n 1, Fascicle 11, 129- 150.

Beldjoudi, H., Delouis, B., Heddar, A., Nouar, O., Yelles-Chaouche, A., 2011. The Tadjena Earthquake (Mw = 5.0) of December 16, 2006 in the Cheliff Region (Northern Algeria): Waveform Modelling, Regional Stresses, and Relation with the Boukadir Fault. Pure and Applied Geophysics, Doi: 10.1007/s00024-011-0337-8.

Belhai, D., 1987. Massif du Chenoua (Algérie): mise en place des flyschs en relation avec un cisaillement dextre transcurrent EW responsable de la structure en éventail. Magister Thesis, Science and Technology Houari Boumédienne University of Algiers, Algeria

Belhai, D., Merle, O., Saadallah, A., 1990. Transpression dextre à l'Éocène supérieur dans la chaîne des Maghrébides (massif du Chenoua, Algérie). Comptes Rendus de l'Académie des Sciences, Paris, Série 2, 310 (06), 795 - 800.

Benhallou, H., Ferrer, A. and Roussel, J., 1971. Catalogue des séismes algériens de 1951 à 1970. Institut de Météorologie et de Physique du Globe de l'Algérie (IMPGA). University of Algiers, Algeria

Benhallou, H., 1985. Les catastrophes sismiques de la région d'Echelif dans le contexte de la sismicité de l'Algérie. Ph.D. Thesis, Science and Technology Houari Boumédienne University of Algiers, Algeria

Benouar, D., 1994. Materials for the investigation of the seismicity of Algeria and adjacent regions during the twentieth century. Special Issue of Annali di Geofisica, 37, 459-860. 
574

575

576

577

578

579

580

581

582

583

584

585

586

587

588

589

590

591

592

593

594

595

596

597

598

599

600

601

602

603

604

605

606

Berberian, M., 1979. Earthquake faulting and bedding thrust associated with the Tabas e Goldshan (Iran) earthquake of December 16, 1978. Bulletin Seismological Society of America 69, 1861-1887.

Bessaoud, O., 1980. La révolution agraire en Algérie: continuité et rupture dans le processus de transformations agraires. Tiers-Monde 21, 605-626.

Bezzeghoud, M., Ayadi, A., Sebaï, A., Ait Messaoud, A., Mokrane, A., and Benhallou, H., 1996. Seismicity of Algeria between 1365 and 1989: Map of Maximum observed intensities (MOI), Avances en Geofisica y Geodesia 1, ano 1, Ministerio de Obras Publicas, Transportes y Medio Ambiante, Instituto Geografico National España, 107-114.

Blès, J -L., 1971. Etude tectonique et microtectonique d'un massif autochtone tellien et sa couverture de nappes: le massif de Blida (Algérie du Nord). Bulletin de la Société Géologique de France 13 (5-6), 498-511.

Bonneton, J. R., 1977. Géologie de la zone de contact entre la Mitidja et l'Atlas de Blida au sud d'Alger. Ph.D. Thesis, Pierre and Marie Curie University of Paris, France

Boudiaf, A., 1996. Etude sismotéctonique de la région d'Alger et de la Kabylie (Algérie): Utilisation des modèles numériques de terrain (MNT) et de la télédétection pour la reconnaissance des structures tectoniques actives: contribution à l'évaluation de l'aléa sismique. Ph.D. Thesis, Montpellier II University, France

Bounif, A., Bezzeghoud, M., Dorbath, L., Legrand, D., Deschamps, A., Rivera, L. and Benhallou, H., 2003. Seismic source study of the 1989, October, Chenoua (Algeria) earthquake from aftershocks, broad-band and strong ground motion records. Annals of Geophysics 46 (4), 625-646.

Bounif, A., Dorbath, C., Ayadi, A., Meghraoui, M., Beldjoudi, H., Laouami, N., Frogneux, M., Slimani, A., Alasset, J.P., Kharroubi, A., Oussadou, F., Chikh, M., Harbi, A., Larbes, S., Maouche, S., 2004. The 21 May, 2003. (Mw 6.8) Zemmouri (Algeria) earthquake relocation and aftershock sequence analysis. Geophysical Research Letters31, L19606, doi:10.1029/2004GL020586.

Carminati, E., Wortel, M. J. R., Spakman, W., Sabadini, R., 1998. The role of slab detachment process in the opening of the western central Mediterranean basins: Some geological and geophysical evidence. Earth and Planetary Science Letters. 160, 651-665.

De Lamothe, G., 1911. Les anciennes lignes de rivage du Sahel d'Alger et d'une partie de la côte Algérienne. Memoires de la Société Géologique de France, 4eme Série, I, Mémoire $\mathrm{N}^{\circ} 6$. 
607

608

609

610

611

612

613

614

615

616

617

618

619

620

621

622

623

624

625

626

627

628

629

630

631

632

633

634

635

636

637

638

639

640

DeMets, C., Gordon, R., Argus, D.F., Stein, S., 1990. Current plate motions. Geophysical Journal International 181, 425-478.

Deschamps, A., Gaudemer, Y. and Cisternas, A., 1982. The El Asnam, Algeria, earthquake of 10 October 1980: multiple source mechanism determined from long period record. Bulletin of the Seismological Society of America 72, 1111-1128.

Déverchère, J., Yelles, K., Domzig, A., Mercier de Lépinay, B., Bouillin, J.P., Gaullier, V., Bracène, R., Calais, E., Savoye, B., Kherroubi, A., Le Roy, P., Pauc, H., Dan, G., 2005. Active thrust faulting offshore Boumerdes, Algeria, and its relations to the $2003 \mathrm{Mw} 6.9$ earthquake. Geophysical Research Letters 32, L04311, doi: 10.1029/2004GL021646.

Déverchère, J., Mercier de Lepinay, B., Cattaneo, A., Strzerzynski, P., Calais, E., Domzig, A., Bracene, R., 2010. Comment on "Zemmouri earthquake rupture zone (Mw 6.8, Algeria): aftershocks sequence relocation and 3D velocity model" by Ayadi et al. Journal of Geophysical Research 115, B04320, doi: 10.1029/2008JB006190.

Domzig, A., 2006. Déformation active et récente, et structuration tectonosédimentaire de la marge sous-marine algérienne. Ph.D. Thesis, University of Western Brittany, France

Domzig, A., Yelles A-K., Le Roy, C., Déverchère, J., Bouillin, J.-P., Bracene, R., Mercier de Lépinay, B., Le Roy P., Calais, E., Kherroubi, A., Gaullier, V., Savoye, B. and Pauc, H., 2006. Searching for the Africa-Eurasia Miocène boundary offshore western Algeria (MARADJA'03 cruise). Comptes Rendus Geoscience 338, 80-91.

Duggen, S., Hoernle, K., Van den Bogaard, P., Harris, C., 2004. Magmatic evolution of the Alboran region: The role of subduction in forming the western Mediterranean and causing the Messinian Salinity Crisis, Earth and Planetary Science Letters 218, 91-108.

Durand-Delga, M., 1969. Mise au point sur la structure du Nord-Est de la Berberie. Bulletin of Geological Algeria Card Service, 39, 89-131.

Frizon De Lamotte, D., Saint Bezar, B., Bracene, R., Mercier, E., 2000. The two main steps of the Atlas building and geodynamics of the western Mediterranean. Tectonics 19, 740761.

Gere, J. M., Shah, H. C., 1984. Terra non firma: Understanding and preparing for earthquakes. Freeman, New York, USA

Glangeaud, L., 1932. Etude géologique de la région littorale de la province d'Alger. Book Edited by Cadoret Y., 1932, Bordeaux, France

Glangeaud, L., Aymé, A., Caire, A., Mattauer, M., et Miraour, P., 1952. Histoire géologique de la province d'Alger. XIX international geological congress Algiers, regional Monographs first series, Algeria, $141 \mathrm{pp}$. 
641 Guemache, M. A., 2010. Evolution géodynamique des bassins sismogénes de l'Algérois 642 (Algérie) Approche pluridisciplinaire (Méthodes Géologiques et Géophysiques), Ph.D. 643 Thesis, Science and Technology Houari Boumédienne University of Algiers, Algeria

644 Guemache, M. A., Djellit, H., Ymmel, H., Gharbi, S., Dorbath, C., 2010. The Post-Astian 645 Bouinan-Soumâa fault (area of Blida, Southern border of the Mitidja Basin, Algeria): 646 Neotectonic expression and implication in seismic hazard assessment. Bulletin of 647 Geological Algeria Card Service, 21(1), 75-94.

648 Gueguen, E., Doglioni, C., Fernandez, M., 1998. On the post-25 Ma geodynamic evolution of 649 the western Mediterranean. Tectonophysics 298, 259-269.

650 Hamaï, L., 2011. Etude gravimétrique de la Mitidja Occidentale, memory magister 651

652

653

654

655

656

657

658

659

660

661

662

663

664

665

666

667

668

669

670

671

672

673

674 geophysics, Science and Technology Houari Boumédienne University of Algiers, Algeria

Hamdache, M., Peláez, J.A., Talbi, A., López Casado, C., 2010. A Unified Catalog of Main Earthquakes for Northern Algeria from A.D. 856 to 2008. Seismological Research Letters 81 ( 5),732-739.

Harbi, A., 2006. Evaluation de l'aléa sismique en Algérie du nord par la modélisation de l'input sismique dans les zones urbaines et l' 'etablissement d'un catalogue. Ph.D. Thesis, Science and Technology Houari Boumédienne University of Algiers, Algeria

Harbi, A., Maouche, S., Ayadi, A., Benouar, D., Panza, G.F., Benhallou, H., 2004. Seismicity and tectonics structures in the site of Algiers and its surroundings: A step towards microzonation. Pure and applied geophysics, 161, 949-967.

Harbi, A., Maouche, S., Vaccari, F., Aoudia, A., Oussadou, F., Panza, G.F., Benouar, D., 2007a. Seismicity, Seismic Input and Site effects in the Sahel-Algiers Region (North Algeria). Soil Dynamics and Earthquake Engineering 27 (5), 427-447.

Harbi, A., Maouche, S., Ousadou, F., Rouchiche, Y., Yelles-Chaouche, A., Merahi, M., Heddar, A., Nouar, O., Kherroubi, A., Beldjoudi, H., Ayadi, A., Benouar, D., 2007 b. Macroseismic study of the Zemmouri Earthquake 21 May 2003 (Mw 6.8, Algeria). Earthquake Spectra 23 (2), 315-332.

Hée, A., 1950. Catalogue des séismes algériens de 1850 à 1911. Annales de 1'Institut de Physique du Globe, Strasbourg, 6, 41-49, France

Higgins, C., Coates, D. R., 1990. Groundwater and geomorphology, the role of subsurface water in Earth-surface processes and landforms. Geological Society of America Special Paper, 252, 368pp.

Jolivet, L., Faccenna, C., 2000. Mediterranean extension and Africa-Eurasia collision. Tectonics 19 (6), 1095-1106. 
675 King, G.C.P. and Vita-Finzi, C., 1981. Active folding in the Algerian earthquake of 10 October 1980, Nature 292, 22-26.

Maouche, S., Benouar, D., Harbi, A., Benhallou, H., 1998. The Algiers (Algeria) Earthquake of 4 September 1996. European Earthquake Engineering journal, 10 (1), 51-55.

Maouche, S., Meghraoui, M., Morhange, C., Belabbes, S., Bouhadad, Y., Haddoum, H., 2011. Active coastal thrusting and folding, and uplift rate of the Sahel Anticline and Zemmouri earthquake area (Tell Atlas, Algeria). Tectonophysics 509(1-2), 69-80.

Mauffret, A., Frizon de Lamotte, D., Lallemant, S., Gorini, G., Maillard, A., 2004. E-W opening of the Algerian Basin (West Mediterranean). Terra Nova 16, 257-264.

McCalpin, J. P., 2009. Paleoseismology, 2nd ed., International Geophysics Series, Academic Press, London, 613pp.

McCalpin, J. P., Bruhn, R. L., Pavlis, T. L., Gutierrez, F., Guerrero, J., Lucha, P., 2011. Antislope scarps, gravitational spreading, and tectonic faulting in the western Yakutat microplate, south coastal Alaska. Geosphere, 7, 1143-1158.

Meghraoui, M., 1988. Géologie des zones sismiques du nord de l'Algérie (Paléosismologie, Tectonique active et synthèse sismotectonique). Ph.D. Thesis, Paris-Sud University, Centre d'Orsay, France

Meghraoui, M., 1991. Blind reverse faulting system associated with the Mont ChenouaTipasa earthquake of 29 October 1989 (north-central Algeria). Terra Nova 3, 84-93.

Meghraoui, M., Philip, H., Albarede, F., Cisternas, A., 1988. Trench investigations through the trace of the $1980 \mathrm{El}$ Asnam thrust fault: evidence from paleoseismicity. Bulletin of the Seismological Society of America 78(2), 979-999.

Meghraoui, M., Maouche, S., Chemaa, B., Cakir, Z., Aoudia, A., Harbi, A., Alasset, P-J., Ayadi, A., Bouhadad, Y., Benhamouda, F., 2004. Coastal uplift and thrust faulting associated with the $\mathrm{Mw}=6.8$ Zemmouri, (Algeria) earthquake of 21 May 2003. Geophysical Research Letters, 31, L19605, doi: 10. 1029/2004GL020466.

Mokrane, A., Ait Messaoud, A., Sebaï, A., Ayadi, A., Bezzeghoud, M., Benhallou, H., 1994. Les séismes en Algérie de 1365 à 1992. Publication du Centre de Recherche en Astronomie, Astrophysique et Géophysique (C.R.A.A.G), Algiers, Algeria. 277 pp.

Oussadou, F., 2002. Contribution à la sismotectonique de l'Algérie occidentale par la sismicité, les mécanismes au foyer, les mesures de déformation et la tectonique générale. Memory magister geophysics, Science and Technology Houari Boumédienne University of Algiers, Algeria 
Ouyed, M., Meghraoui, M., Antenor-Habazac, C., Bourezg, S., Cisternas, A., Dorel, J., Frechet, J., Frogneux, M., Hatzfeld, D., Philip, H., 1980. Le séisme d'E1Asnam du 10 Octobre 1980, premiers résultats sismologiques et tectoniques. Comptes rendus de l'Académie des sciences de Paris, Tome 291.

Ouyed, M., Meghraoui, M., Cisternas, A., Deschamps, A., Dorel, J., Frechet, J., Gaulon, R., Hatzfeld, D., Philip, H., 1981. Seismotectonics of the El Asnam earthquake. Nature 292, 26-31.

Ouyed, M., Yielding, G., Hatzfeld, D., and King, G. C. P., 1982. An aftershock study of the Al-Asnam( Algeria) earthquake of 1980 October 10. Geophysical Journal of the Royal Astronomical Society, 73, 605-639.

Perrey, A., 1847. Note sur les tremblements de terre en Algérie et dans l'Afrique septentrionale. Memoirs of the Academy of Sciences Arts and Belles Lettres, Dijon, France, 299-323.

Philip, H., Meghraoui, M., 1983. Structural analysis and interpretation of the surface deformation of the Asnam earthquake of October 10, 1980. Tectonics 2, 299-349.

Reicherter, K., Becker-Heidmann, P., 2009. Tsunami deposits in the western Mediterranean: remains of the 1522 Almería earthquake? Geological Society, London, Special Publication, 316, 217-235.

Reimer, P. J., Baillie, M. G. L., Bard, E., Bayliss, A., Beck, J. W., Backwell, P. G., Ramsey, C. B., Buck, C. E., Burr, G. S., Edwards, R. L., Friedrich, M., Grootes, P. M., Guilderson, T. P., Hadjas, I., Heaton, T. J., Hogg, A. G., Hughen; K. AL, Kaiser, K. F., Kromer, B., McCormac, F. G., Manning, S. W., Reimer, R. W., Richards, D. A., Southon, J. R., Talamo, S., Turney, C. S. M., Van der Plucht, J., Weyhenmeyer, C. E., 2009. IntCal09 and Marine09 radiocarbon age calibration curves, 0-50,000 years cal BP. Marine Chemistry and Geochemistry 51, 1111-1150.

Rothé, J.P., 1950. Les Séismes de Kherrata et la simicité de l'Algérie. Bulletin of Geological Algeria Card Service, 4th series, Geophysics, 3, pp. 40.

Rothé, J.P., 1955. Le tremblement de terre d'Orléanville et la sismicité de l'Algérie. La Nature, 3237.

Roussel, J., 1973. Les zones actives et la fréquence des séismes en Algérie. North Africa Bulletin of Natural History Society, 64(3/2), 11-22.

Saadallah, A., 1981. Le massif cristallophyllien d'El-Djazaïr (Algérie) : Evolution d'un charriage à vergence nord dans les internides des Maghrébides. Ph.D. Thesis, Science and Technology Houari Boumédienne University of Algiers, Algeria 
742 Saoudi, N., 1989. Pliocène et Pléistocène inférieur et moyen du Sahel d'Alger. ENAG, Algiers, Algeria, 174 pp.

Schettino, A., Turco, E., 2006. Plate kinematics of the Western Mediterranean region during the Oligocene and Early Miocene. Geophysical Journal International 166, 1398-1423.

Sebaï, A., 1997. Analyse sismologique des séismes récents du Sahel d’Alger. Memory magister geophysics, Science and Technology Houari Boumédienne University of Algiers, Algeria

Sebaï, A., Bernard, P., 2008. Contribution à la connaissance de la sismicité d'Alger et de ses alentours au XVIIIe siècle, extraite des archives françaises. Comptes Rendus Geoscience 340, 495-512.

Serpelloni, E., Vannucci, G., Pondrelli, S., Argnani, A., Casula, G., Anzidei, M., Baldi, P., Gasperini, P., 2007. Kinematics of the Western Africa-Eurasia plate boundary from focal mechanisms and GPS data, Geophysical Journal International, 169 (3), 1180-1200.

Stich, D., Serpelloni, E., Mancilla, F. D. L., Morales, J., 2006. Kinematics of the IberiaMaghreb plate contact from seismic moment tensors and GPS observations. Tectonophysics 426, 295-317.

Thomas, G., 1976. Mise en évidence de décrochements dextres Est-Ouest d'âge quaternaire en Algérie nord occidentale. Comptes rendus de l'Académie des sciences de Paris, France, série D 283, 893-896.

Vergès, J., Sabàt F., 1999. Constraints on the Western Mediterranean kinematics evolution along a 1000-km transect from Iberia to Africa. In: B. Durant, L. Lolivet, F. Horvarth and

Strzerzynski, P., Déverchère, J., Cattaneo, A., Domzig, A., Yelles, K., Mercier de Lépinay, B., Babonneau, N. and Boudiaf, A., 2010. Tectonic inheritance and Pliocene-Pleistocene inversion of the Algerian margin around Algiers: Insights from multibeam and seismic reflection data. Tectonics 29, TC2008, doi:10.1029/2009TC002547. Geological Society of London, Special Publication 156, 63-80.

Yelles-Chaouche, A.K, Deramchi A, Ferkoul, A., Aoulaiche, K., 2002. Les séismes d'Algérie du Nord de 1992-2001. Catalogue of Centre de Recherche en Astronomie, Astrophysique et Géophysique (CRAAG), Algeria.

Yelles, A.K., Lammali, K., Mahsas, A., 2004. Coseismic deformation of the May 21st, 2003, 
775

776

777

778

779

780

781

782

783

784

785

786

787

788

789

790

791

792

793

794

795

796

797

798

799

800

801

802

803

804

805

806

807

808

Yelles, A.K., Domzig, A., Déverchère, J., Bracène, R., Mercier de Lépinay, B., Strzerzynski, P., Bertrand, G., Boudiaf, A., Winter, T., Kherroubi, A., Le Roy, P., Djellit, H., 2009. Evidence for large active fault offshore west Algiers, Algeria, and seismotectonic implications. Tectonophysics 475, 98-116.

Yelles, A.K., Boudiaf, A., Djellit, H., Bracene, R., 2006. La tectonique active de la région Nord-algérienne. Comptes Rendus Geoscience 338, 126-139.

Yielding, G., Jackson, J.A., King, G.C.P., Sinvhal, H., Vita-Finzi, C. and Wood, R.M., 1981. Relations between surface deformation, fault geometry, seismicity, and rupture characteristics during the El Asnam (Algeria) earthquake of 10 October 1980. Earth and Planetary Science Letters 56, 287-305.

\section{Table caption}

Table 1: measured and corrected ages of samples collected in the trench. Measured ages have been corrected for the atmospheric ${ }^{14} \mathrm{C} /{ }^{13} \mathrm{C}$ ratio over the last few millennia using IntCal, an on-line CALIB Manual 6.0 radiocarbon calibration tool hosted by the Quaternary Isotope Laboratory at the University of Washington, UK (http://calib.qub.ac.uk). For each sample, a probability density and a relative area under probability distribution are obtained (Reimer et al., 2009). Charcoal samples smaller than $0.2 \mathrm{mgC}$ were removed because they do not give reliable ages. Samples associated with a "plateau" calibrated age were considered "Modern", corresponding to a maximum age of $1750 \mathrm{AD}$ (Reimer et al., 2009).

\section{Figure captions}

Figure 1. Seismotectonic map of Algiers and its surroundings. Shaded bathymetric (from MARADJA cruise) and topographic (90 m-SRTM DEM) maps showing offshore (Domzig et al., 2006; Strzerzynski et al., 2010) and onshore faults (Meghraoui, 1988; Boudiaf, 1996; Yelles et al., 2006) (lines). Focal mechanisms of main shock (Mw>4.9) (Deschamps et al., 1982; Bounif et al., 2003; 2004; Beldjoudi et al., 2011; GFZ; Havard CMT) associated with epicentres of principal earthquakes after 1980 (stars). Open squares show the location of the significant historical earthquakes and dotted open squares show the location of doubtful historical earthquakes (Benouar, 1994; Harbi et al., 2007a). White dots correspond to epicentres of instrumental seismicity $(\mathrm{Mw}>2)$ (Benouar, 1994; extraction from C.R.A.A.G. Catalogue, 1994, 2002, 2011).

Figure 2. Geological map of the Algiers region showing the Sahel ridge and faults (Strzerzynski et al., 2010; Maouche et al., 2011). B : Geological cross-section of the Sahel 
809 ridge according to Maouche et al. (2011). C: Geological cross-section of the Sahel ridge 810 according to Aymé et al. (1954). For location see figure 1.

811 Figure 3. Views of Pliocene formations cropping out at the bottom of the southern flank of 812 the Sahel structure. A: Layers of Pliocene marls and sandstones at site 1 dipping $31^{\circ}$ to the 813 SE. B: Layers of Upper Pliocene sandstones at site 2 dipping $84^{\circ}$ to the SE. For location see 814 Figure 2.

815 Figure 4. Geomorphological and geological context of the study zone. A: A SPOT satellite 816 image (5m-resolution) indicates a morphologic scarp and the location of the cross-section in 817 Figure 5B and the trench sites shown in Figures 5, 6 and in auxiliary material. B: Geological 818 cross-section showing the relationship between the major Sahel thrust and the studied 819 secondary faults. For location see Figure 2.

820 Figure 5. Paleoseismological trench wall exhibiting the graben structure outcropping in the southern flank of the Sahel structure. Grid has $50 \mathrm{~cm}$ mesh. Trench location is denoted on Figures $2 \mathrm{~A}$ and 4 . A and B: detail of the trench showing deformation markers associated with motion along the faults. C: View of the trench wall. B: Log of the trench. Faults are lines

824 labelled A to E. White stars indicate the age and the location of the samples dated with 825 radiocarbon analyses. Stratigraphic contacts are shown in thin black lines with encircled black 826 numbers representing the unit name. Units: 1: Quaternary conglomerates with angular pebbles 827 well consolidated in a silty matrix, 2: Quaternary white marls of alteration clay, 3, 4 and 5: 828 deposits with gravels in a silty clay matrix, 6 and 7: silty clays containing shells and detrital 829 charcoal, 8: peat horizon, 9, 10, 11 and 12: brown silty clays.

830 Figure 6. Outcrop of the studied zone affected by normal faults. A: Picture of the outcrop. B: 831 Interpretation of the outcrop. Location shown on Figure 4.

832 Figure 7. Inferred sequence of deformation, sedimentation and erosion at the trench. See text 833 for details.

834 Figure 8. Diagram of age ranges of paleo-events (horizontal red lines) and dates of historical 835 earthquakes (vertical thick lines: $I=\mathrm{VIII}$; vertical thin lines: $I=\mathrm{IX}$ or $\mathrm{X}$, dotted lines are 836 doubtful earthquakes. Below the graph, certain historical earthquakes are reported in black, 837 doubtful earthquakes are reported in grey).

\section{Appendix}

840 Paleoseismological trench wall exhibiting alluvial deposits located on the morphological 841 scarp 200-m downward the graben structure outcropping in the southern flank of the Sahel 842 structure. Grid has $100 \mathrm{~cm}$ mesh. Trench location is denoted on Figure 4. A and B: View of 
843 the trench wall. C: Log of the trench. Stratigraphic contacts are shown in thin black lines with 844 encircled black letters representing the unit name. Unit UA correspond to Quaternary marls. 845 Units UB to UT are alluvial units, dominantly conglomerates with some sandy horizons.

846 


\begin{tabular}{|c|c|c|c|c|c|c|c|}
\hline Sample & Unit & $\begin{array}{c}\text { Measured } \\
\text { age BP }\end{array}$ & $\begin{array}{l}\text { Calibrated } \\
\mathrm{AD} \text { age } \\
\text { range }\end{array}$ & $\begin{array}{c}\text { Probability } \\
\%\end{array}$ & $\begin{array}{l}\text { Relative } \\
\text { area under } \\
\text { probability } \\
\text { distribution }\end{array}$ & $\begin{array}{l}\text { Laboratory } \\
\text { specimen } \\
\text { number }\end{array}$ & $\begin{array}{c}\text { Specimen } \\
\text { Detail }\end{array}$ \\
\hline e1 & $\mathrm{U} 4$ & $1170 \pm 20$ & $778-897$ & $95.4(2 \sigma)$ & 0.918 & UGAMS 8873 & Helix \\
\hline e2 & U6 & $100 \pm 1$ & Not reliable & & & Poz-41032 S & $\begin{array}{l}\text { Charcoal } \\
\leq 0.2 \mathrm{mgC}\end{array}$ \\
\hline $\mathrm{e} 3$ & U7 & $860 \pm 20$ & 1171-1211 & $68.3(1 \sigma)$ & 1 & UGAMS 08872 & Helix \\
\hline e4 & U8 & $210 \pm 60$ & Not reliable & & & Poz-41033 S & $\begin{array}{l}\text { Charcoal } \\
\leq 0.2 \mathrm{mgC}\end{array}$ \\
\hline e5 & U8 & $150 \pm 30$ & $1727-1779$ & $68.3(1 \sigma)$ & 0.42 & Poz-41039 & $\begin{array}{l}\text { Charcoal } \\
>0.2 \mathrm{mgC}\end{array}$ \\
\hline e6 & U9 & $570 \pm 30$ & $1304-1365$ & $95.4(2 \sigma)$ & 0.603 & Poz-41036 & $\begin{array}{l}\text { Charcoal } \\
>0.2 \mathrm{mgC}\end{array}$ \\
\hline e7 & U9/U10 & $101 \pm 1$ & Modern & & & Poz-41038 & $\begin{array}{l}\text { Charcoal } \\
>0.2 \mathrm{mgC}\end{array}$ \\
\hline e8 & $\mathrm{U} 10$ & $100 \pm 30$ & Modern & & & -41037 & $\begin{array}{l}\text { Charcoal } \\
>0.2 \mathrm{mgC}\end{array}$ \\
\hline e9 & U11 & $230 \pm 70$ & Not reliable & & & Poz-41034 S & $\begin{array}{l}\text { Charcoal } \\
\leq 0.2 \mathrm{mgC}\end{array}$ \\
\hline $\mathrm{e} 10$ & U12 & $320 \pm 50$ & $1455-1654$ & $95.4(2 \sigma)$ & & Poz-41040 S & $\begin{array}{l}\text { Charcoal } \\
>0.2 \mathrm{mgC}\end{array}$ \\
\hline e11 & soil & $75 \pm 50$ & Modern & & & Poz-41041 & $\begin{array}{l}\text { Charcoal } \\
>0.2 \mathrm{mgC}\end{array}$ \\
\hline
\end{tabular}

Table 1: measured and corrected ages of samples collected in the trench. Measured ages have been corrected for the atmospheric ${ }^{14} \mathrm{C} /{ }^{13} \mathrm{C}$ ratio over the last few millenia using IntCal, an on-line CALIB Manual 6.0 radiocarbon calibration tool hosted by the Quaternary Isotope Laboratory at the University of Washington, UK (http://calib.qub.ac.uk). For each sample, a probability density and a relative area under probability distribution are obtained (Reimer et al., 2009). Charcoal sample smaller than 0.2 $\mathrm{mgC}$ were removed because that give not reliable age. Samples associated with a "plateau" calibrated age were qualified of "Modern" corresponding to a maximum age of 1750 AD (Reimer et al., 2009). 

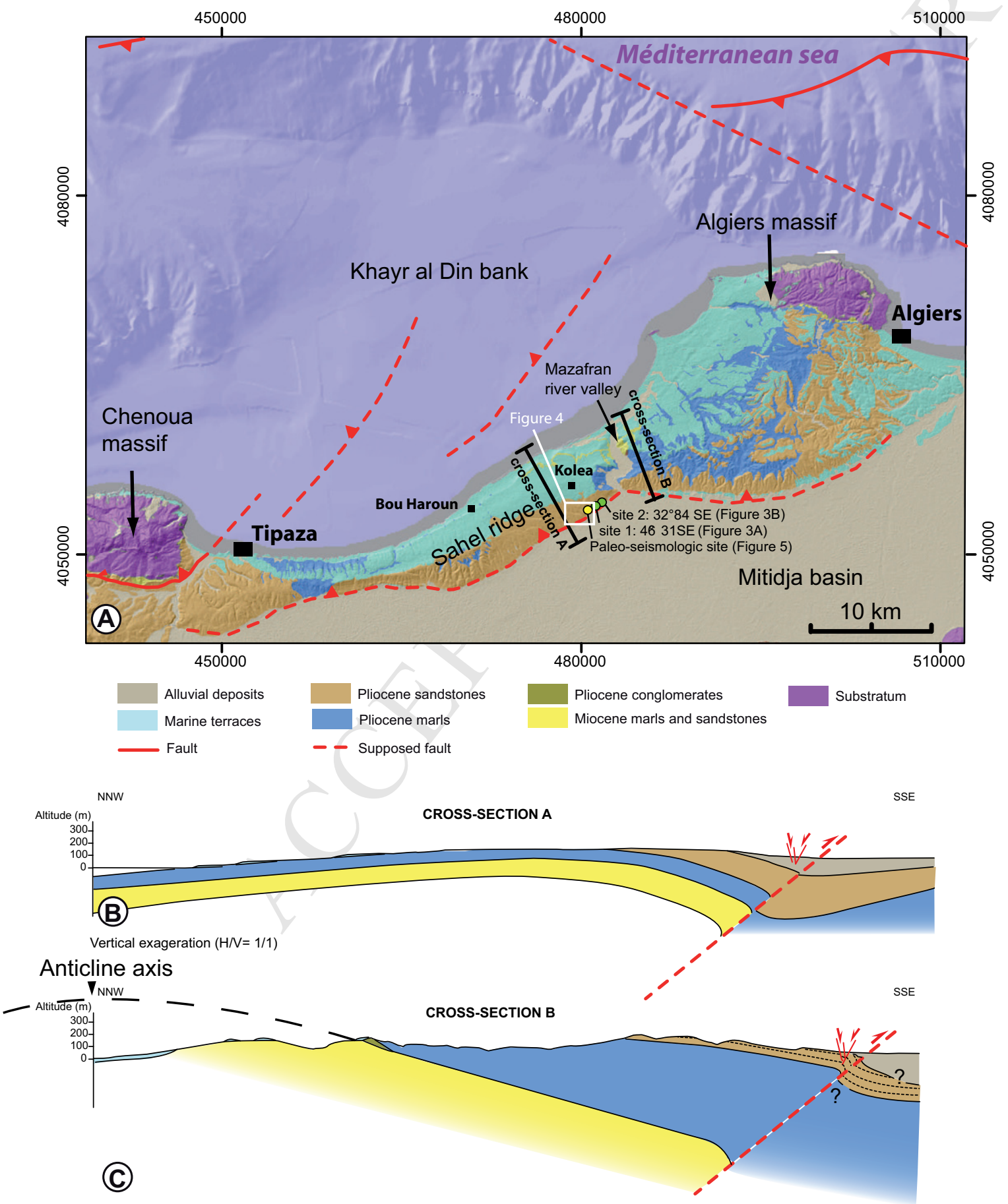

Vertical exageration $(H / V=1 / 1)$

Figure 2 

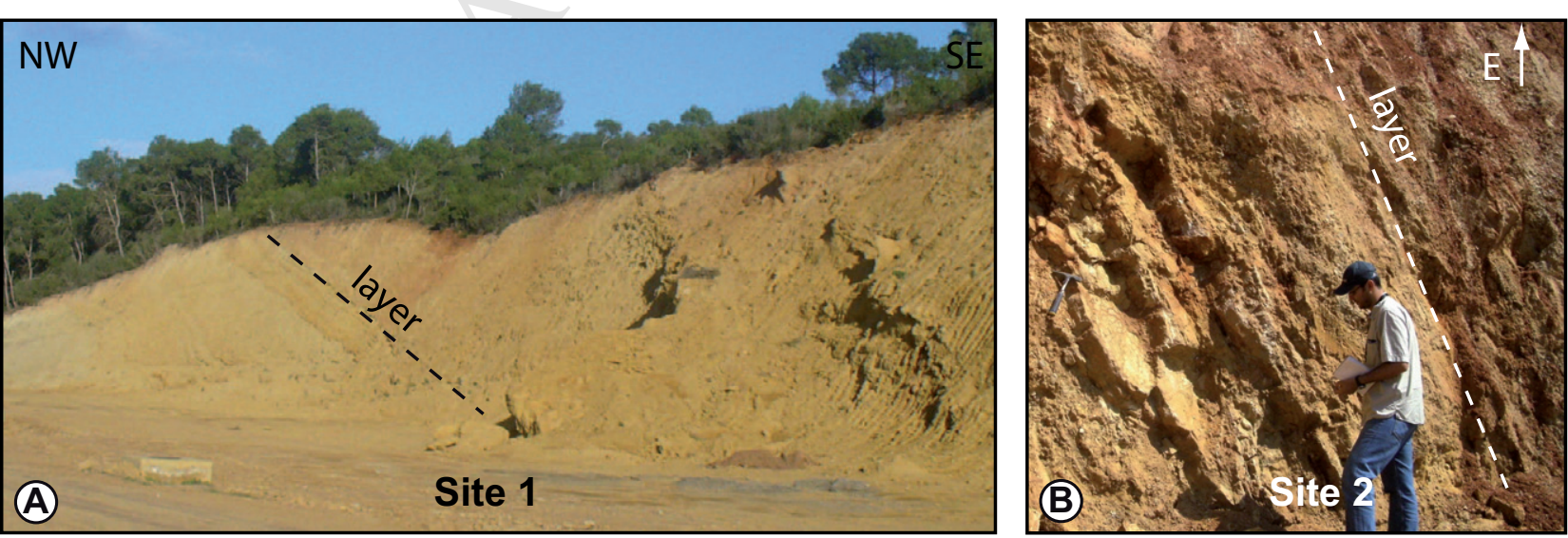

Figure 3 

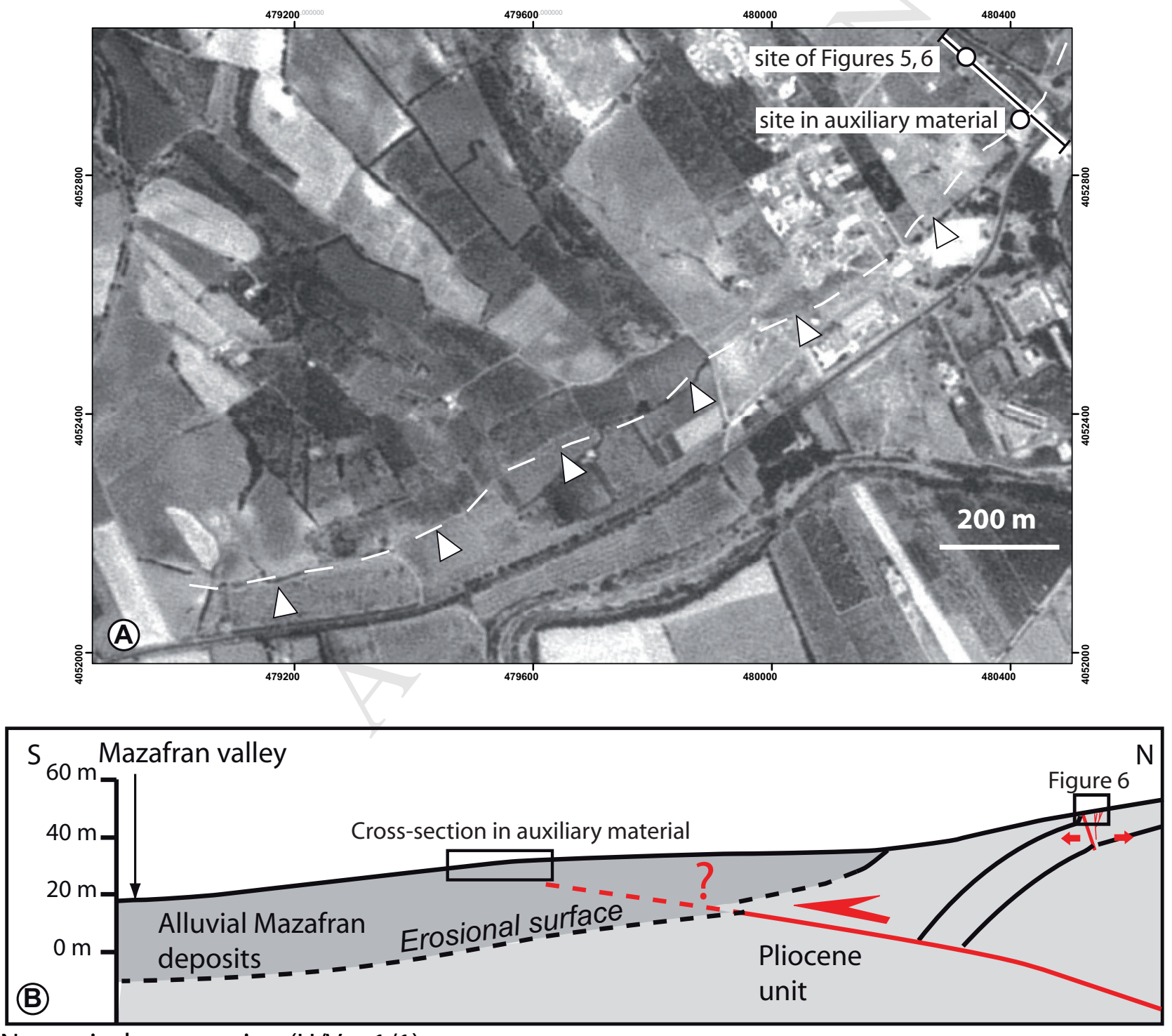

No vertical exageration $(\mathrm{H} / \mathrm{V}=1 / 1)$

Figure 4 

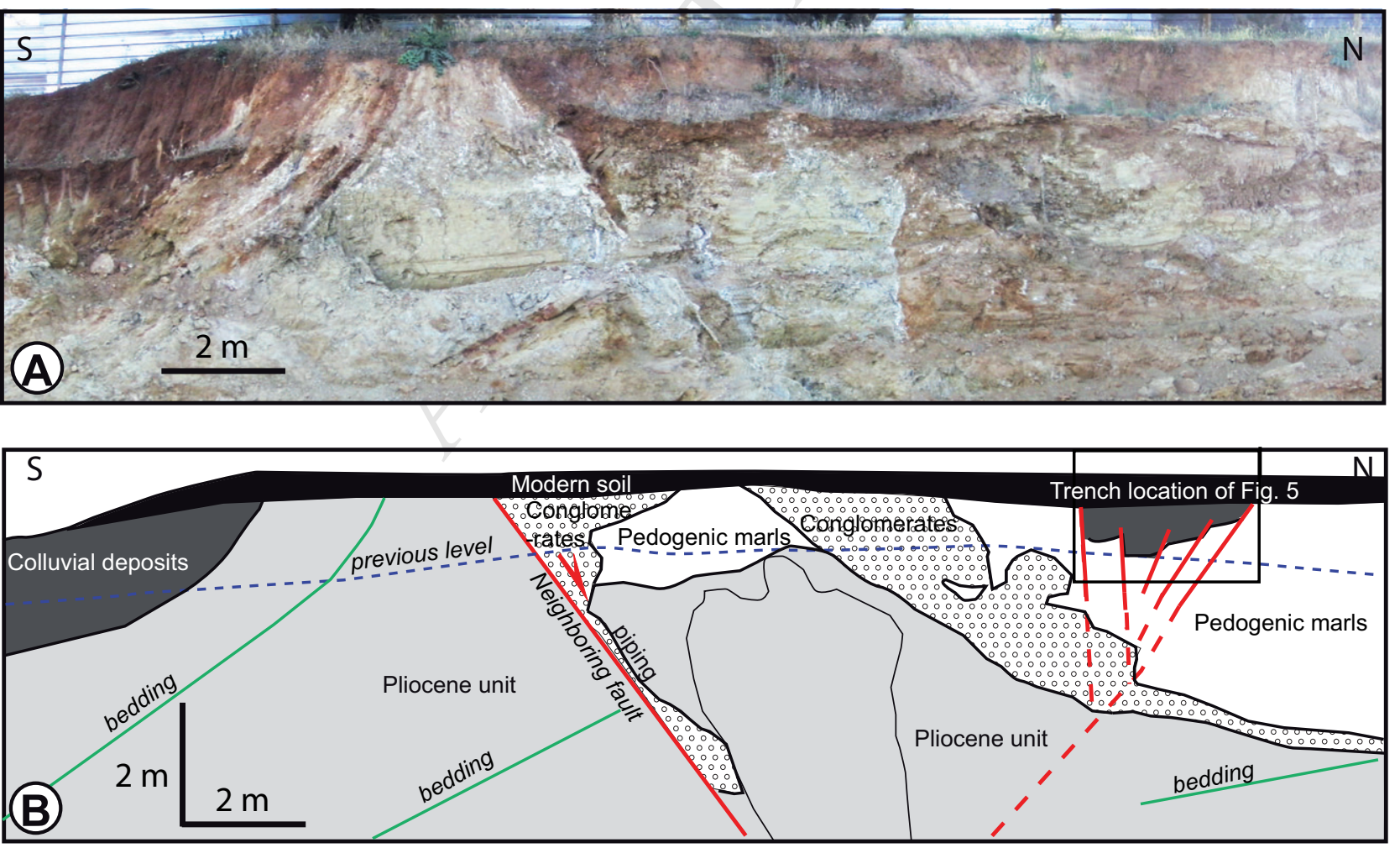

Figure 6 


\section{SEQUENCE OF EVENTS}

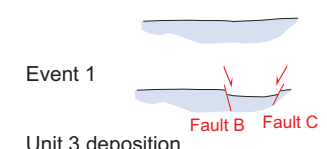

Unit 3 deposition

Event 2

Unit 4 deposition

$\longrightarrow$

Event 3

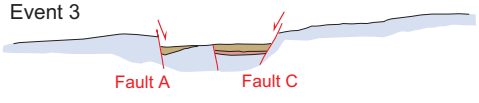

Unit 5 deposition

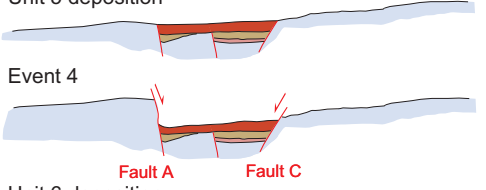

Unit 6 deposition

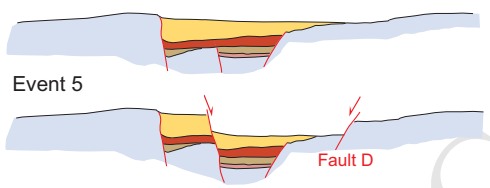

Units 7 and 8 deposition
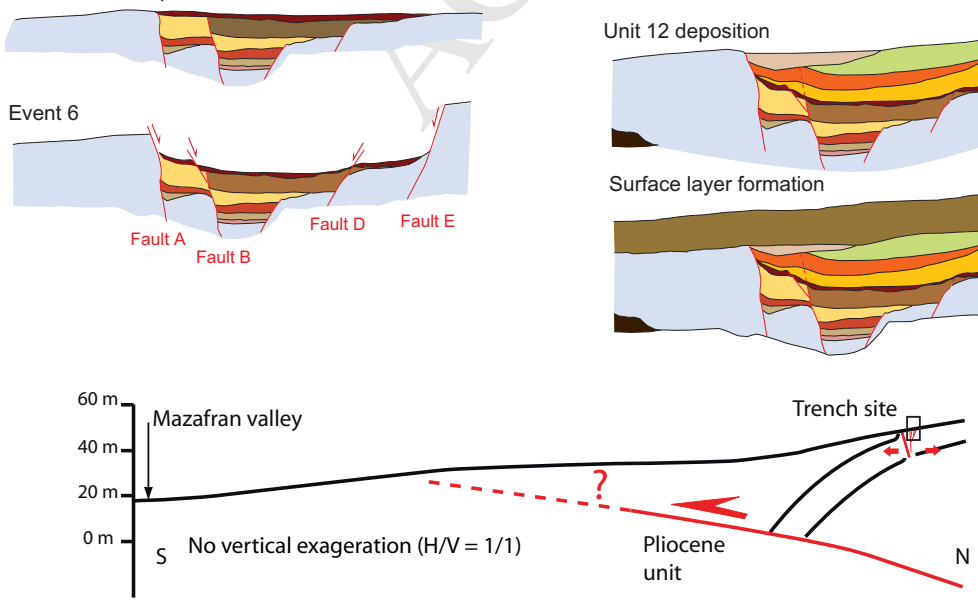

Figure 7
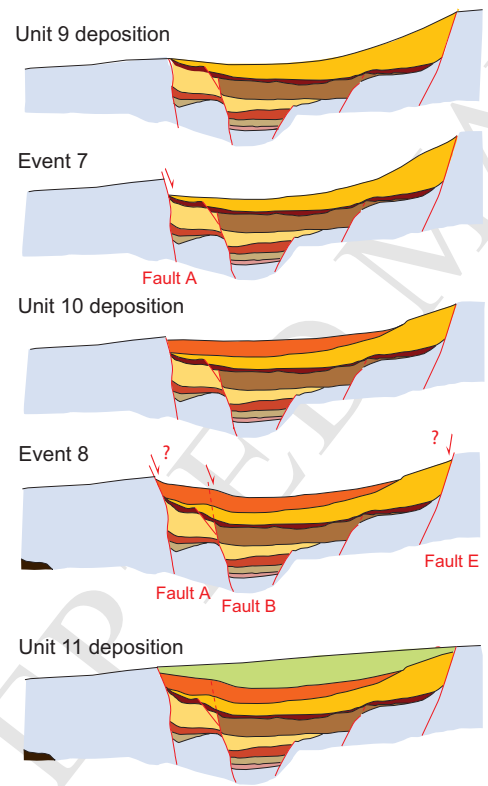

Erosion

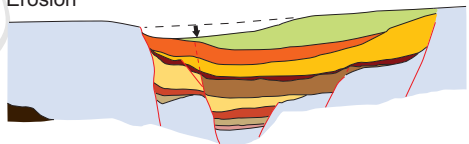

Unit 12 deposition

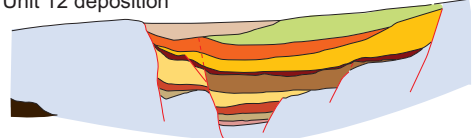

Surface layer formation

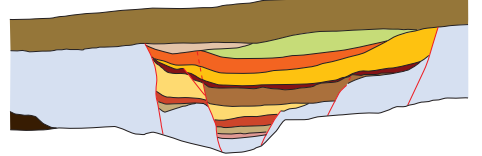




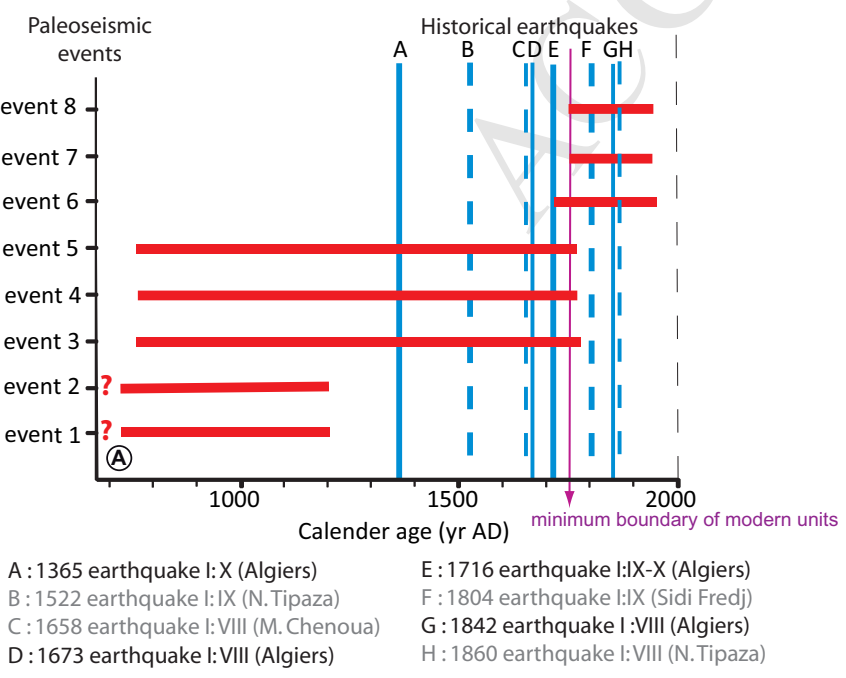

\section{Figure 8}




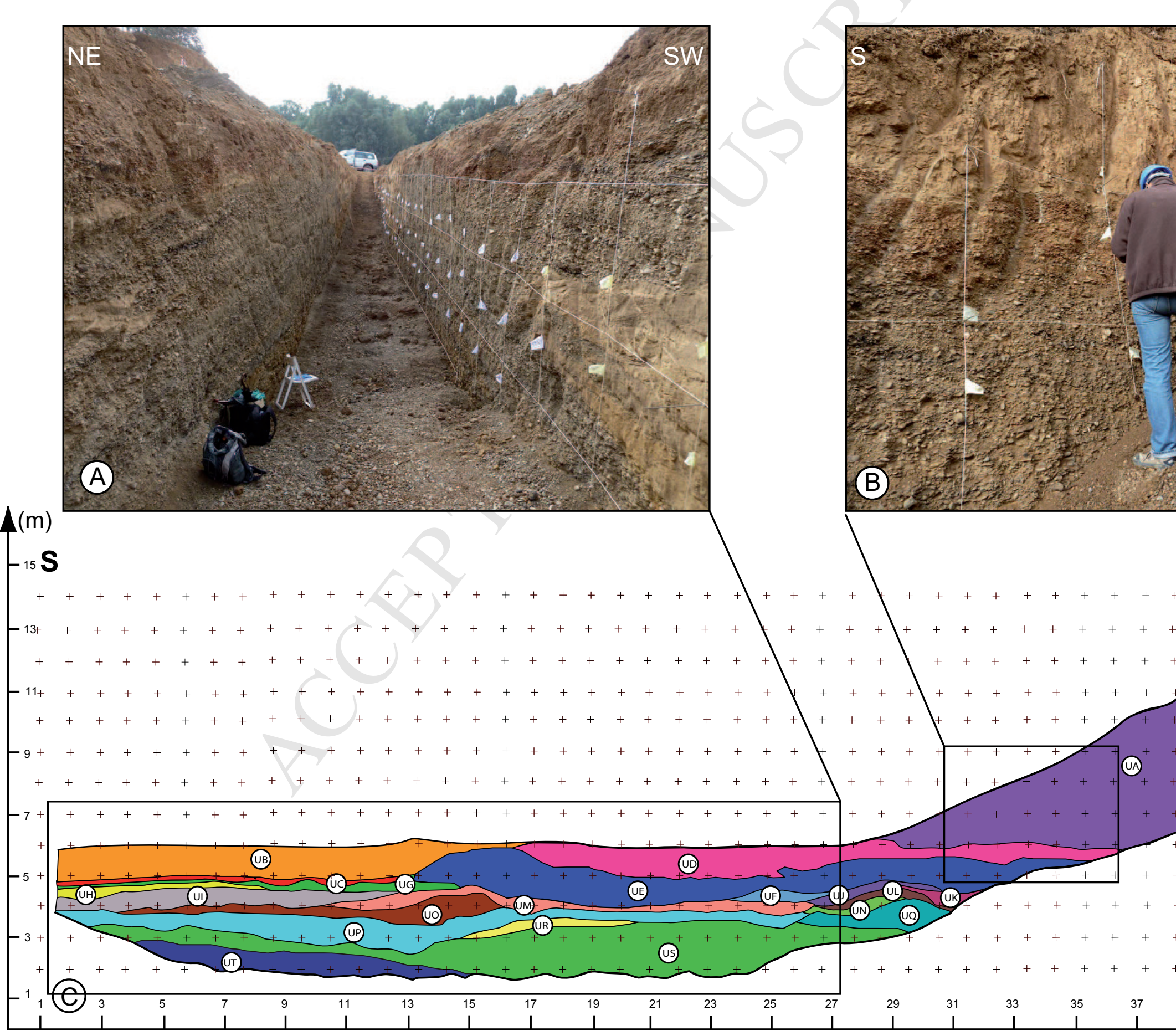

